Vol. $43 \cdot 2021$

\section{Marek Zawada}

(D) https://orcid.org/0000-0002-0036-4547

Chair of Management Processes

Faculty of Management

Warsaw University of Technology,

Warsaw, Poland

marek.zawada.dokt@pw.edu.pl

\section{Dorota Gągala}

(D) https://orcid.org/0000-0001-9383-3850

Department of Scientific Research

and International Cooperation

Division Clinical Trials

The Children's Memorial Health Institute,

Warsaw, Poland

d.gagala@ipczd.pl

\title{
An analysis of certification processes for Good Clinical Practice and project management competencies
}

Accepted by Editor Ewa Ziemba | Received: October 10, 2020 | Revised: March 2, 2021; April 21, 2021; May 18, 2021 | Accepted: May 20, 2021 | Published: June 9, 2021.

(C) 2021 Author(s). This article is licensed under the Creative Commons Attribution-NonCommercial 4.0 license (https://creativecommons.org/licenses/by-nc/4.0/)

\begin{abstract}
Aim/purpose - The purpose of this paper is to clarify the certification process of the Good Clinical Practice (GCP) competencies based on a comparison with the project management (PM) certification process. This aim was accomplished by model development.

Design/methodology/approach - The study was divided into three main phases: 1 st phase - the identification of key characteristics of PM and GCP certification processes, 2nd phase - the development of certification models for PM and GCP, 3rd phase - the conclusions from in-depth interviews.

Findings - As a result of the research, key characteristics of PM and GCP certification processes were identified, certification models for PM and GCP were developed. In addition, based on conclusions from in-depth interviews, solutions for organizing the way of confirming knowledge of GCP guidelines were proposed.

Research implications/limitations - The proposed rules may be too complex and may exceed the needs and expectations of the clinical trial environment. The models focus on stakeholder relations, without the rules of certification granting procedures, to enable broader contextualization of the issues discussed in the paper. The analysis might be fragmented as it regards the sole certification process. The research refers to Poland only, hence it will be valuable to identify whether foreign authorities have the same attitude to the GCP competency certification model. It is recommended to increase the number of respondents' interviews to obtain results of higher validity and reliability.
\end{abstract}

Cite as: Zawada, M., \& Gągała, D. (2021). An analysis of certification processes for Good Clinical Practice and project management competencies. Journal of Economics \& Management, 43, 179-205. https://doi.org/ 10.22367/jem.2021.43.09 
Originality/value/contribution - The paper raises research topics at the crossroads of project management, clinical trials, and GCP, topics that have been underdeveloped so far. The results might be significant for all organizations involved in conducting clinical research projects. The findings contribute to the quality of clinical trials and provide public assurance that the rights, safety, and well-being of trial subjects are protected and the clinical trial data are credible.

Keywords: project management, clinical trials, certification, Good Clinical Practice, GCP. JEL Classification: M10, O32, I11.

\section{Introduction}

Today's global economy is called the knowledge economy (Jones \& Shideh, 2021, p. 1; Wang, Zhang, Xiong, \& de Pablos, 2020, p. 207). Knowledge is the key engine of economic growth based on four pillars: the labor force that should be composed of educated and skilled workers, a modern and adequate information infrastructure, an effective innovation system, and institutional regimes (World Bank, 2007, pp. 23-24). Professionalization and the requirement of a high level of competence have become emblematic of current times (Oleksyn, 2010 , p. 9). This is characteristic of knowledge workers who are often distinguished by the fact that they have certificates confirming the state of their knowledge (Patalas-Maliszewska, 2019, p. 36). They are an essential resource for organizations because knowledge workers (being a source of tacit knowledge), through their experience and knowledge, contribute to increasing the effectiveness of the organization (Schmidt, Bell, \& Warren, 2021).

Currently, many organizational initiatives in many areas of the economy are carried out in the project formula (Juchniewicz, 2018, p. 44). A project is a new, unusual initiative implemented within an organization, different from routine activities (Pawlak, 2006, p. 17). With a specific goal, a specific baseline, and deadline, a limited budget, human and material resources involved, a project is a multifunctional phenomenon (Kerzner, 2013, p. 2). It is indicated that knowledge is the most critical resource for project management (Gasik, 2010, p. 2). The key competencies are also the ability to use knowledge in practice, as well as knowledge of tools and techniques of project work (Nazeer \& Marnewick, 2018, pp. 52-53). This study covers two areas where competencies (particularly knowledge) and their confirmation are necessary: conducting clinical trials and project management.

Clinical trials are a major component of the drug development process, and their value is constantly increasing in Poland (PwC, 2015). The number of ongoing research projects, both commercial and noncommercial, is also growing 
(Urząd Rejestracji Produktów Leczniczych, Wyrobów Medycznych i Produktów Biobójczych [Office for Registration of Medicinal Products, Medical Devices and Biocidal Products], 2020). They constitute a foundation for the development of medicine, contribute to the development of the healthcare market and general economic development. In the healthcare sector, as in other areas of the economy, projects play an important role (Prawelska-Skrzypek \& Jałocha, 2014). What is more important, clinical trials meet all requirements of the project definition (Doganov \& Yanev, 2006).

Project management is such an evolving discipline that a need for verification of knowledge, skills, and competencies related to it has arisen (Remer \& Ross, 2014; Starkweather \& Stevenson, 2010; Swain, 2000). This is reflected in the possibility of certification granted by many entities around the world (e.g., Project Management Institute, International Project Management Association, APMG, etc.). There are also numerous examples of adaptations of guidelines, standards, and practices in the field of project management in clinical trial management (Goodarzynejad \& Babamahmoodi, 2015; Parvathaneni, Pattarkine, \& Chappidi, 2018; Shirley, 2020).

Conducting clinical trial projects requires the expertise and skills of various regulation guidelines and the awareness of Good Clinical Practice (GCP), a golden standard for conducting clinical trials. GCP is an international ethical and scientific quality standard for designing, conducting, recording, and reporting trials involving human subject participation. The ICH GCP Tripartite Guidelines for Good Clinical Practice resulted from the work of the International Council for Harmonisation of Technical Requirements for Registration of Medicinal Products for Human Use (ICH-GCP). In 1996, the ICH GCP was adopted by EMA with the latest update in 2002 (European Medicines Agency, 2002) and by FDA with the latest update in 2018 (The United States Food and Drug Administration, 2018). The compliance with this standard provides public assurance that the rights, safety, and well-being of trial subjects are protected, consistent with the principles that have their origin in the Declaration of Helsinki, and that the clinical trial data are credible (The United States Food and Drug Administration, 2018).

Since a clinical trial should be considered as a project (Doganov \& Yanev, 2006), we can take for granted that competence and certification standards should be similar in both clinical trials/GCP and project management fields. However, the authors' experience indicates that these standards and the understanding of the certification and the certification processes differ significantly, the perception of wording 'a certificate' and 'the certification', in particular. This insight served as the impetus for this research. 
We might conclude that reliable, credible confirmation of competencies is essential, especially in the healthcare sector. This proof would be possible by adopting existing, acknowledged and worldwide project management standards to the GCP area since they may not be satisfactory in the GCP area. A literature review made by the authors revealed a paucity of research on GCP competency and certification. In addition, there is a lack of literature showing the possible benefit switch from the certification principles of the project management knowledge to the GCP field. This area constitutes a research gap that the authors attempt to fill.

This paper aims at clarifying the certification of the GCP competencies process based on a comparison with the project management certification process. This goal is accomplished by model development. The research work includes the identification and characteristics of the current way of verifying the knowledge of GCP guidelines and the skills and their comparison with the certification system of project management competency. Differences between certificates and certification in these areas were analyzed. In addition, the authors proposed the GCP and the Project Management certification model describing stakeholder relations and interactions among them. As a supporting research method confirming the accuracy of the described process (and relations among stakeholders) reflected by the GCP model, individual in-depth interviews were used and conducted with the sponsors' representatives of clinical trials, e.g., pharmaceutical companies and academies.

A clarification of the difference between a certificate and certification allows adumbrating an effective way to verify the knowledge and the skills to transfer training effects into everyday practice. This shift should contribute to the improvement of the quality of clinical trials and consequently to the safety of trial subjects and the quality of data.

The structure of the paper is as follows. First, the theoretical background is presented, and a research gap is identified. Then, the methodology stages are listed. The research findings ( 3 phases: identifying key characteristics of PM and GCP certification processes, developing certification models for PM and GCP, and in-depth interview results) are delivered in the penultimate section. The paper ends with the final discussion and conclusions. 


\section{Background}

Certification and accreditation is a topical issue and relates to many fields, including management systems (Kohl, 2020) and healthcare (Cilenti, 2021). Certification can increase sales and improve market position for both small and larger enterprises (Calza \& Goedhuys, 2021, pp. 17-18). Obtaining certification also has a significantly positive impact on good investor relations (Cheng, Sharma, Shen, $\& \mathrm{Ng}, 2021$, p. 133). Even during the COVID-19 pandemic, challenges in conducting certification processes are examined (Nowicki \& Kafel, 2021).

Much of the research is concerned with explaining the exact nature of certification. Wawak (2009) defines certification as a process of verifying and confirming that an organization meets the requirements set out in the standards. Its primary stage is the certification audit. An independent external auditor verifies the entire scope of the company's activities in terms of meeting the requirements. The result of these activities is the issue of a certificate (Wawak, 2009). Certificates are an element of the operationalization of competence management. They confirm the level of knowledge and skills understood as a combination of knowledge and practice. Moreover, certificates increase the credibility of competence, protecting employers, customers, and contractors from incompetence and low-quality products, among other things (Oleksyn, 2010, pp. 217-218). Cambridge Dictionary defines certification as: "the process of giving official or legal approval to a person, company, product, etc. that has reached a particular standard" and as: "a proof or a document proving that someone is qualified for a particular job, or that something is of good quality" (Cambridge Dictionary, n.d.).

Blomquist, Farashah, \& Thomas (2018, p. 499) indicated that a certification merely provides evidence that a person has met a certain minimum standard of practice. In contrast, many scholars and practitioners argue that certification means affirming that a person is fit to practice. Furthermore, this person is more competent to practice than someone who is not certified.

In the literature, the studies addressing the differences between certification and a certificate can be found. It would also be necessary to consider whether a certificate is necessary at all. Some of the literature suggested that certification by itself does not improve the effectiveness of a project manager's (regardless of years of experience) and is a too small component of the knowledge dimension to be meaningful (Catanio, Armstrong, \& Tucker, 2013, p. 8). Another question is whether the certification is sufficient because of other possible factors influencing the rate of successful projects (Catanio et al., 2013, p. 15). 
Comparing the dictionary definitions of these terms, one can conclude that a certificate is a piece of paper. At the same time, certification is the process for demonstrating proficiency and comprehension in a given field. A certificate is proof that specific requirements have been met, for example, a course, and certification is proof of knowledge and experience (Quality Magazine, 2016). The Institute for Credentialing Excellence presents a similar position. It clearly shows differences: "Demonstration of accomplishment of the intended learning outcomes by participants is NOT a requirement for receiving the certificate; thus, possession of a certificate of attendance or participation does NOT indicate that the participant has accomplished the intended learning outcomes. These are key distinctions between a certificate of attendance or participation and an assessment-based certificate program" (Institute for Credentialing Excellence, 2010 , p. 3). Such differences are reported by many organizations that aim at education and competence development in the healthcare sector, including the American Association of Legal Nurse Consultants (n.d.) and Public Responsibility in Medicine and Research (n.d.).

Accreditation is another term related to the subject in question. This is a process of obtaining a quality certificate from registered accreditation bodies after going through a proper evaluation of the quality standards implemented by an organization. It aims at improving service quality and helps gain public reputation and global prestige (Swapan \& Bhaswati, 2020).

Bracewell \& Winchester (2021) indicated that organizations working in the medical field, mainly hospitals, make efforts to obtain accreditation of the medical services they provide. However, accreditation methods are heterogeneous and do not guarantee that best practices will be followed daily. Moreover, Y1ld1z, Öztürk, Topal, \& Khan (2019, p. e1676) stated that there is a paucity of research on whether accreditation of hospitals contributes to the improvement of management performance and quality of health facility processes. In the case of healthcare entities, accreditation is offered for the entire system and specific components, such as medical education, medical laboratories, tissue banks, air ambulance services, and public health organizations (Y1ldiz et al., 2019, p. e1676).

Research concerning the benefits of validating competencies through certification is being undertaken. Due to the complexity of project management and the growing importance of projects in the organization's activities (the phenomenon is referred to as 'projectification') (Blomquist et al., 2018, p. 510; Juchniewicz, 2018, p. 44), the need to confirm the competence in this area has arisen. The issue of project management certification, in particular, the following ques- 
tions: 'who offers training' and 'who provides certification testing', has been analyzed for a long time (Swain, 2000). Project management knowledge and skills should be verified and confirmed by formulating adequate tests and examinations as well as by issuing relevant certificates which confirm the state of knowledge and skills. Some organizations have developed sets of guidelines, methodologies, methods, and standards for project management that are successfully implemented in many organizations around the world.

Kerzner (2013, p. 1098) pointed out that organizations that value the professionalism of project management adopt the Project Management Institute's Certification Program as their standard. The certification confirms professionalism and makes it clear that high standards of project management are essential for organizations.

However, studies showed that having a certified project manager does not translate into an increased probability of success (Starkweather \& Stevenson, 2010, p. 39). Similar results were obtained in projects, where the discrepancy between the expected benefits at the strategic level and the benefits reported by project managers at the project level was indicated (Wells, 2012). It was also pointed out that there is a possibility of losing the significance of the acquired certificates, especially when certification programs are introduced to the market as a necessary condition for organizations to implement projects and for people to become project managers. The risk of losing the significance of the certificate also occurs when formal requirements for certification are included in the transnational regulatory process (Hallgren, Nilsson, Blomquist, \& Soderholm, 2012, p. 474).

International institutions generally address the topic of the clinical trial management system and the certification of competence in this field. The main one is The World Medical Association (World Medical Association, 2018), which has developed the Declaration of Helsinki as a statement of ethical principles for medical research involving human subjects, including research on identifiable human materials and data. Consistent with the mandate of the WMA, the Declaration is addressed primarily to physicians. The WMA encourages others who are involved in medical research concerning human subjects to adopt these principles. The guidance was developed with consideration of the current Good Clinical Practices of the European Union, Japan, and the United States and those of Australia, Canada, the Nordic countries, and the World Health Organization (European Medicines Agency, 2002). However, this document, as a guidance document, does not establish legally enforceable responsibilities. Instead, the guidance describes the agency's current thinking on a topic and should be 
viewed only as recommendations unless specific regulatory or statutory requirements are cited. The use of the wording in agency guidance means that something is suggested or recommended but not required (The United States Food and Drug Administration, 2018). To implement the ICH-GCP guidelines as a law, the European Union promulgates the following legal acts: Clinical Trial Directive (Directive 2001/20/EC), GCP Directive - DIRECTIVE 2005/28/EC (Directive 2005/28/EC), Regulation on clinical trials on medicinal products for human use, and repealing Directive 2001/20/EC (Regulation 536/2014), so has done Poland promulgating the Act Prawo Farmaceutyczne (Ustawa z dnia 6 września 2001 r. Prawo farmaceutyczne [Act of 6 September 2001. Pharmaceutical law]) and the Regulation on GCP (Rozporządzenie Ministra Zdrowia z dnia 2 maja 2012 r. w sprawie Dobrej Praktyki Klinicznej [Regulation of the Minister of Health of 2 May 2012 on Good Clinical Practice]) and other EU countries, by promulgating their national regulations.

Considerations on applying GCP began before introducing the EU Directive 2001/20/EC (Englev \& Petersen, 2003). Now, they aim at defining the principles of its application and emphasizing its importance (Fougerou-Leurent et al., 2020).

\section{Research methodology}

The research process aimed at identifying and describing the certification process in two areas: project management and GCP knowledge. The study was divided into 3 (three) main phases: 1st phase - the identification of key characteristics of PM and GCP certification processes, 2nd phase - the development of certification models for PM and GCP, 3rd phase - the conclusions from in-depth interviews.

First, a literature review was conducted. Online resources of scientific journals were scanned, especially in the field of management science, including the following keywords: 'certification', 'certificate', 'project management', 'Good Clinical Practice', 'clinical trial' and their combinations. It was meant to cover the main concepts and research areas discussed in the study: project management, clinical trial management, Good Clinical Practice (GCP) regulations, and certification process. Based on the literature, exploring the main features of the certification process and the stakeholders involved in it, similarities and differences were analyzed between the project and clinical trial management process and between project management and GCP certification approaches. 
The key characteristics for PM certification processes were collected directly from the reference materials out of selected organizations (PMI, IPMA, APG Group, Scrum Alliance). However, those for GCP - were identified based only on one source, i.e., TransCelerate, Biopharma Inc. (due to the lack of such organizations' counterparts in the GCP area).

Second, the models of GCP and project management certification process were identified and prepared. The project management certification model was created based on the literature. The GCP certification model was developed based on the authors' experience due to the paucity of literature on this topic, considering the similarities and differences identified with the project management certification process.

As a third stage, to confront the compiled models with practice and empirically examine how the GCP guidance system is perceived, in-depth interviews were chosen because it is the best method to provide insight into an individual developed point of view (Legard, Keegan, \& Ward, 2014, pp. 138-139).

The aim of in-depth interviews, conducted by the authors in person in July 2020, was to verify the GCP certification model by examining the expectations of clinical trial sponsors concerning Good Clinical Practice (GCP) certification. The number of conducted interviews was limited to five because of the qualitative character of the questionnaire and the limited availability of respondents. The respondents were selected intentionally from experts, researchers, and clinical trial sponsors cooperating with The Children's Memorial Health Institute in Warsaw (Department of Scientific Research and International Cooperation), taking into consideration position taken, experience, and present activities. The questions were addressed to representatives of the sponsors, experts in clinical trial management, who in their professional work are responsible for conducting clinical trial projects following ICH-GCP guidelines.

The authors constructed a one-round survey consisting of seven questions and sent it electronically to respondents who answered back on the Microsoft Forms web platform. The interviews concerned, among other things, the following issues: What does the need for GCP certification result from? Which entities are entitled to conduct GCP training? Are there any entities that grant accreditation to GCP training providers? What are the possible sources of knowledge on GCP? Is the current GCP certification system sufficient to verify the knowledge of the GCP guidelines reliably? How is the level of GCP knowledge verified? Should changes be made to the process of certifying/confirming knowledge of the GCP guidelines? Then, in-depth telephone interviews were conducted personally by the authors based on the responses received. The answers were written down during the interviewing process, then analyzed, taking into considera- 
tion the similarities and differences between respondents' answers. The detailed information about the interviewed experts, the interview questions, and examples of selected responses are presented in the Appendix.

\section{Research findings}

\subsection{The identification of key characteristics of PM and GCP certification processes}

The recognition of project management as a separate way of organization work and management method has been significantly influenced by organizations such as the Project Management Institute (PMI), International Project Management Association (IPMA). These organizations have disseminated many standards, best practices, and procedures (Strojny \& Szmigiel, 2015, p. 251).

Among many types of projects, there is a group of IT projects for which certificates are provided to a narrow group of specialists. These are CISCO Certified Associate (for CISCO network devices) and Information Technology Project Plus (issued by CompTIA for IT specialists) (Pietras \& Szmit, 2003, pp. 63-64). An example of a certificate confirming knowledge of guidelines (code of conduct) concerning the management and provision of operational IT services is the ITIL (IT Infrastructure Library) certificate (Axelos, n.d.).

The best known and valued organizations that provide project management certification are Project Management Institute (PMI), International Project Management Association (IPMA), APMG (APM Group), Scrum Alliance (Strojny $\&$ Szmigiel, 2015, p. 258). Selected characteristics of the certificates granted by the listed organizations are presented in Table 1.

Table 1. Selected characteristics of project management certificates

\begin{tabular}{|c|c|c|c|c|}
\hline Characteristics & $\begin{array}{l}\text { Project Management } \\
\text { Institute }\end{array}$ & $\begin{array}{c}\text { International Project } \\
\text { Management } \\
\text { Association }\end{array}$ & APM Group & Scrum Alliance \\
\hline 1 & 2 & 3 & 4 & 5 \\
\hline $\begin{array}{l}\text { Certificate } \\
\text { name }\end{array}$ & $\begin{array}{l}\text { 1. Certified Associate } \\
\text { in Project Man- } \\
\text { agement (CAPM). } \\
\text { 2. Project Manage- } \\
\text { ment Professional } \\
\text { (PMP). } \\
\text { 3. Program Manage- } \\
\text { ment Professional } \\
\text { (PgMP) }\end{array}$ & $\begin{array}{l}\text { 1. IPMA-D (Certified } \\
\text { Project Manage- } \\
\text { ment Associate). } \\
\text { 2. IPMA-C (Certified } \\
\text { Project Manager). } \\
\text { 3. IPMA-B (Certified } \\
\text { Senior Project } \\
\text { Manager). } \\
\text { 4. IPMA-A (Certified } \\
\text { Projects Director) }\end{array}$ & $\begin{array}{l}\text { 1. PRINCE2 } \\
\text { Foundation. } \\
\text { 2. PRINCE2 } \\
\text { Practitioner }\end{array}$ & $\begin{array}{l}\text { 1. CSM (Certified } \\
\text { Scrum Master). } \\
\text { 2. CSD (Certified } \\
\text { Scrum Developer). } \\
\text { 3. CSPO (Certified } \\
\text { Scrum Product } \\
\text { Owner) }\end{array}$ \\
\hline
\end{tabular}


Table 1 cont.

\begin{tabular}{|c|c|c|c|c|}
\hline 1 & 2 & 3 & 4 & 5 \\
\hline Difficulty & $\begin{array}{l}\text { 1. Medium. } \\
\text { 2. Difficult. } \\
\text { 3. Difficult }\end{array}$ & $\begin{array}{l}\text { 1. Medium. } \\
\text { 2. Difficult. } \\
\text { 3. Difficult. } \\
\text { 4. Not applicable }\end{array}$ & $\begin{array}{l}\text { 1. Medium. } \\
\text { 2. Difficult }\end{array}$ & $\begin{array}{l}\text { 1. Easy. } \\
\text { 2. Not applicable. } \\
\text { 3. Not applicable }\end{array}$ \\
\hline $\begin{array}{l}\text { Competencies } \\
\text { required }\end{array}$ & $\begin{array}{l}\text { 1. Beginner } \\
\text { managers. } \\
\text { 2. Managers with } \\
\text { a master's degree. } \\
\text { 3. Program managers }\end{array}$ & $\begin{array}{l}\text { 1. Project team } \\
\text { members without } \\
\text { practical } \\
\text { experience. } \\
\text { 2. Project managers. } \\
\text { 3. Managers of large, } \\
\text { complex projects. } \\
\text { 4. Project directors }\end{array}$ & $\begin{array}{l}\text { 1. Knowledge of the } \\
\text { methodology without } \\
\text { the need for practical } \\
\text { application. } \\
\text { 2. Project managers } \\
\text { capable of solving } \\
\text { management prob- } \\
\text { lems and Prince2 } \\
\text { Foundation certifi- } \\
\text { cation }\end{array}$ & $\begin{array}{l}\text { 1. Members and } \\
\text { managers of scrum } \\
\text { teams. } \\
\text { 2. Individuals directly } \\
\text { involved in soft- } \\
\text { ware development. } \\
\text { 3. Business analysts } \\
\text { and managers, } \\
\text { especially product } \\
\text { and team managers }\end{array}$ \\
\hline Scope & $\begin{array}{l}\text { 1. Knowledge } \\
\text { of PMBoK. } \\
\text { 2. PMBoK Guide } \\
\text { and the PMI Code } \\
\text { of Ethics. } \\
\text { 3. PMBoK Guide } \\
\text { and the Standard } \\
\text { for Program } \\
\text { Management }\end{array}$ & $\begin{array}{l}\text { For each certificate: } \\
\text { knowledge of IPMA } \\
\text { Competence Baseline }\end{array}$ & $\begin{array}{l}\text { 1. Knowledge of } \\
\text { methodology and } \\
\text { knowledge Prince2 } \\
\text { Manual. } \\
\text { 2. Knowledge of } \\
\text { Prince2 Manual }\end{array}$ & $\begin{array}{l}\text { For each certificate: } \\
\text { understanding of the } \\
\text { basic knowledge of } \\
\text { project management } \\
\text { and the main princi- } \\
\text { ples of the Scrum } \\
\text { Guide }\end{array}$ \\
\hline $\begin{array}{l}\text { Professional } \\
\text { experience }\end{array}$ & $\begin{array}{l}\text { 1. One year. } \\
\text { 2. Two years. } \\
\text { 3. Three years }\end{array}$ & $\begin{array}{l}\text { 1. A year, but not } \\
\text { necessarily in the } \\
\text { project. } \\
\text { 2. Minimum three } \\
\text { years in project } \\
\text { management. } \\
\text { 3. Five years in } \\
\text { project manage- } \\
\text { ment, including } \\
\text { at least three years } \\
\text { in a management } \\
\text { position. } \\
\text { 4. Five years in } \\
\text { portfolio, program, } \\
\text { or multiple projects } \\
\text { management } \\
\end{array}$ & $\begin{array}{l}\text { 1. No requirements } \\
\text { for output } \\
\text { knowledge } \\
\text { or experience. } \\
\text { 2. No requirements }\end{array}$ & $\begin{array}{l}\text { 1. Completed two-day } \\
\text { Scrum Master } \\
\text { training. } \\
\text { 2. Participation in } \\
\text { a five-day training } \\
\text { course accredited } \\
\text { by Scrum Alliance } \\
\text { (3 days technical } \\
\text { training). } \\
\text { 3. Completion } \\
\text { of two-day training } \\
\text { accredited by the } \\
\text { Scrum Alliance }\end{array}$ \\
\hline $\begin{array}{l}\text { Certificate } \\
\text { validity }\end{array}$ & $\begin{array}{l}\text { 1. Five years. } \\
\text { 2. Three years. } \\
\text { 3. Three years }\end{array}$ & $\begin{array}{l}\text { 1. No time limit. } \\
\text { 2. Four to five years - } \\
\text { renewal based on } \\
\text { an application for } \\
\text { renewal of the } \\
\text { certificate }\end{array}$ & $\begin{array}{l}\text { 1. Granted for life, } \\
\text { without the need } \\
\text { for recertification. } \\
\text { 2. Five years - } \\
\text { renewal based on } \\
\text { a multiple-choice } \\
\text { test examination }\end{array}$ & $\begin{array}{l}\text { For each certificate - } \\
\text { two years - after this } \\
\text { period, it is necessary } \\
\text { to renew it and pay } \\
\text { the membership fee }\end{array}$ \\
\hline
\end{tabular}

Source: Based on: Strojny \& Szmigiel (2015, pp. 259-262); Project Management Institute (n.d.); International Project Management Association (n.d.); APMG (n.d.); Scrum Alliance (n.d.). 
Most of the entities whose certificates are presented in Table 1 grant certification based on an examination whose structure depends on the unit and its examination. The examination consists of a written exam, lasting from one to four hours with test questions, open questions, and sometimes practical tasks based on a case study and an interview with the candidate. The IPMA entity additionally specifies the age at which a candidate can obtain a given certificate: for IPMA-D 20 years, for IPMA-C 25 years, for IPMA-B 30 years, for IPMA-A 35 years. It is required to renew the certificate's validity by passing the examination again or by collecting an appropriate number of training points. In all cases, people have to pay to get a certificate. PMI and IPMA certificates concern project management, whereas those offered by APM only require knowledge of the PRINCE2 methodology. Additionally, IPMA certificates confirm the candidates' knowledge and experience and their managerial and interpersonal competencies, with particular emphasis on personality traits (Strojny \& Szmigiel, 2015, pp. 259-262).

Other project management certification organizations include the American Society for Engineering Management [ASEM] (n.d.) and the Construction Management Association of America [CMAA] (n.d.). Their scope of operation and thus recognition of certificates is limited to the United States (Remer \& Ross, 2014).

The above-mentioned organizations' structure consists of the standard-setting organizations (board of directors) and the organizations that operate under accreditation. The standard-setting organizations providing training and certification for individuals can also accredit organizations that want to provide training and certification. To a large extent, the latter organizations conduct most of the education, training, and examination activities by issuing certificates. Notably, only accredited organizations have the authority to conduct examinations and issue certificates.

Researchers involved in clinical trials are required to follow GCP guidelines and provide proof of being an 'expert in the clinical investigation of drugs' before participating in a clinical study, which can be done with a curriculum vitae showing previous clinical trial experience.

Formal training and certification in GCP are not required (Haeusler, 2009). The only recommendation is stated in Section 2.8 of GCP ICH E6 Guidelines: "Each individual involved in conducting a trial should be qualified by education, training, and experience to perform his or her respective task(s)." This recommendation is usually interpreted by sponsors of clinical trials as:

a) GCP Training is required for trial staff,

b) trials should be built around the GCP framework, and is the primary rationale for initiating a GCP training. 
The GCP training market is unregulated. There are no formalized standardized rules and regulations to indicate which units can provide training and how often it should be renewed. There is also no accreditation body. As a result, any company with a registered training activity (CEIDG Registry in Poland) or a sponsor or a contract research organization (CRO) can provide GCP training. Additionally, an individual who has undergone training and received a GCP certificate (usually the Clinical Research Associate position) can also train other concerned and issue certificates. As a result of the market mechanism, organizations introduce an internal system of quality control of conducted GCP training. Some training companies apply for accreditation in quality systems offered in the country (in Poland - Centrum Monitorowania Jakości w Ochronie Zdrowia [Center for Quality Monitoring in Health Care] or ISO). They also apply for official approval of the content of their training at trade associations in the country (in Poland - e.g., GCP.pl Association). A relatively common method of confirming the quality of their training is the so-called 'accreditation by TransCelerate'. TransCelerate Biopharma Inc. (n.d.) is a non-profit organization. Its Site Qualification and Training (SQT) Initiative has developed a Mutual Recognition (MR) Program for ICH E6 Good Clinical Practice (GCP) Training, targeted at investigator site personnel. To attest to their training course details, they send the training content and a sample of the certificate template via e-mail. Within the framework of this program, the company submitting the course with content is placed on the TransCelerate List of Training Providers, which, according to the environment, ranks them as High-Quality Providers. Interestingly, TransCelerate writes literally (on the website) that it does not provide GCP training, and the GCP Mutual Recognition Program is not a certification program (TransCelerate Biopharma Inc., n.d.). Although obtaining 'accreditation' is not very complicated, the environment considers this form sufficient to perceive the listed training of high quality. It will adequately prepare the research team to conduct the clinical trial according to the GCP principles and has the potential to increase protocol adherence and improve clinical trial quality.

As a result, clinical researchers sometimes have an only superficial knowledge of GCP (Haeusler, 2009). They do have certificates, but regarding details, they are unfamiliar with the records, and their practical conduct contradicts the certified acquired knowledge. Consequently, the ICH-GCP guidelines are a document that necessitates interpretation. Various chargeable studies such as the 700-page Good Clinical Practice Q\&A GCP Reference Guide by Barnett International and Parexel International Corporation (Hulihan, 2017) are prepared 
as a tool, which the sponsor, CRO, or clinical staff may refer to on many occasions. After all, GCP is a complicated and evolving discipline that intersects with several other complex and developing fields, including ethics, medicine and nursing, health systems, regulatory, administrative, and health policy. Reasonable GCP practitioners with varied backgrounds can sometimes disagree on how best to interpret and implement GCP standards and guidelines (Hulihan, 2017).

In summary, there are several significant differences between the certification process for project management and clinical trials. There are many certification standards in project management, all structured. Accreditations awarded to training organizations are formally and internationally recognized. In GCP, there is no certification standard (only guidelines), and there is no formal accreditation. There are training organizations, but they operate independently and local1y. Certificates of training are also only awarded locally. Project management certification can be described as a knowledge-based and competency-based approach - confirmation of knowledge, skills, and competencies (Catanio et al., 2013, p. 15). In contrast, a knowledge-based approach in GCP - focused on providing knowledge and confirming that fact. Both PM and GCP certifications are voluntary (Blomquist et al., 2018).

\subsection{The development of certification models for PM and GCP}

Based on the analysis, two models have been developed: a project management certification model (Figure 1) and a Good Clinical Practice certification model (Figure 2). First, the system's architecture for certification of competencies and skills in project management was identified through literature analysis and the authors' practical experience. Three organizational levels were identified: accrediting bodies, certifying bodies, and certified bodies. Furthermore, the relationships between stakeholders were determined. Then, based on the project management certification model, an analogue one for Good Clinical Practice was built to identify the models' differences clearly. 
Figure 1. Project management certification model

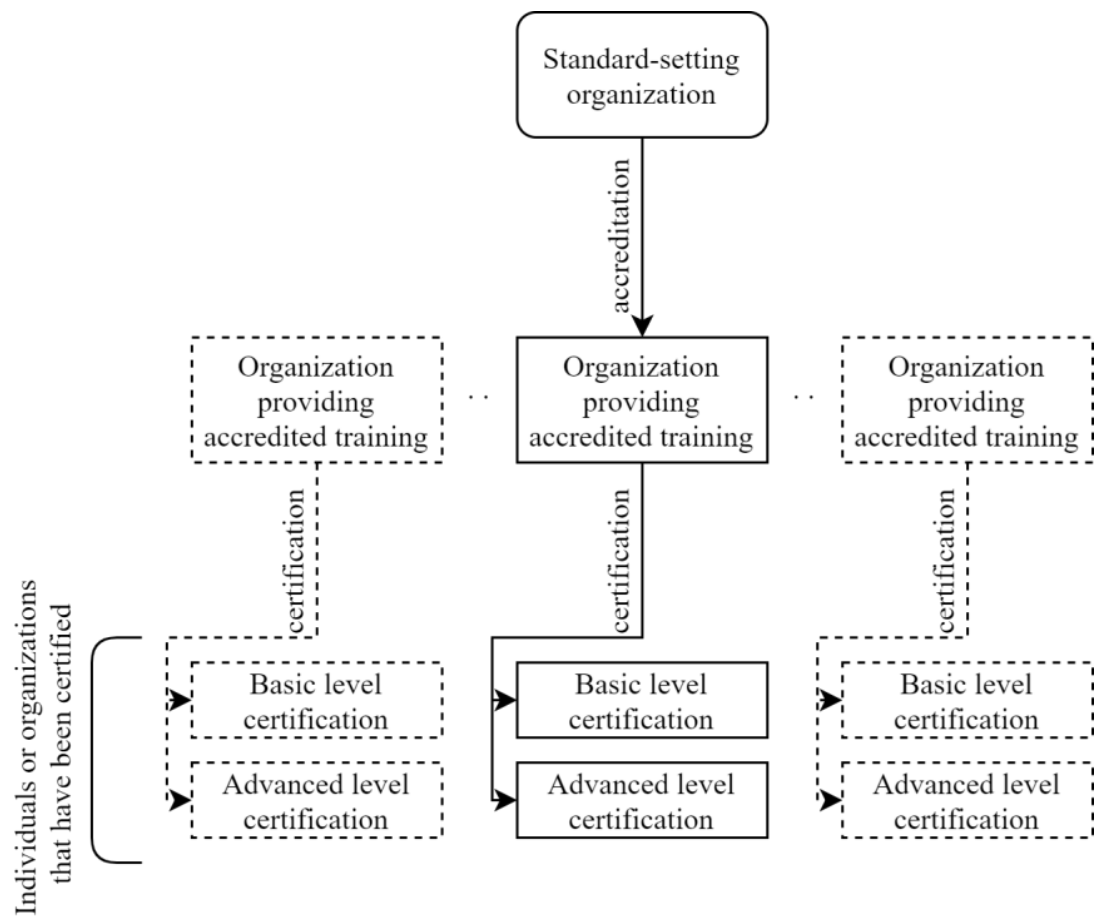

The project management certification model consists of a standard-setting organization, an organization providing accredited training, and individuals or organizations that have been certified. Individuals or organizations that apply for certification should undergo training and then pass examinations conducted by an organization with appropriate accreditation. Accreditation is granted by the organization that is the originator of the specific standards (e.g., the PRINCE2 methodology). There is only one organization granting accreditation, whereas there may be many accredited entities (to conduct training, examinations, and certification). 
Figure 2. Good Clinical Practice certification model

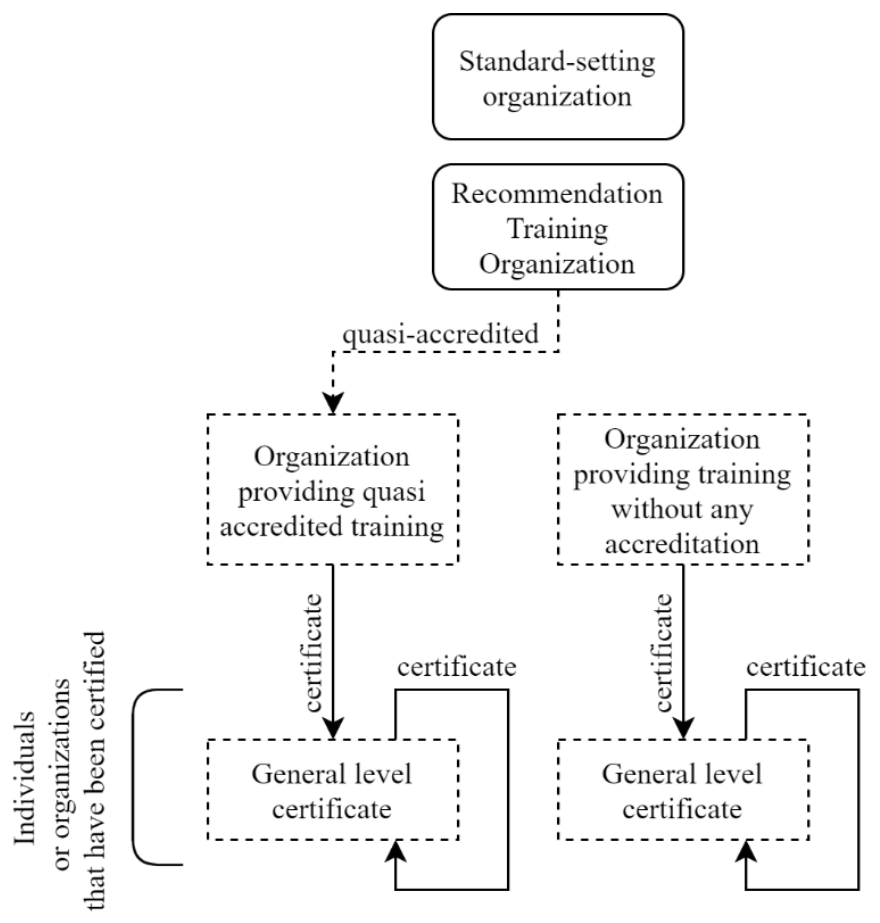

The Good Clinical Practice certification model consists of standard-setting organizations, the Recommendation Training Organization, organizations providing training, and individuals or organizations that have been certified. Organizations providing training and subsequent certification are divided into two groups: which have been accredited and which operate without accreditation. The entity that provides accreditation (actually quasi-accreditation) is TransCelerate BioPharma. The company denies that its activities are a certification program. It does not announce that it grants accreditation but only certifies the content of the training conducted by other entities. There exists only one standard-setting organization - The International Council for Harmonisation of Technical Requirements for Pharmaceuticals for Human Use [ICH] (1996). As regards the certification of knowledge of GCP guidelines, the health sector is not regulated. There are no restrictions on the entities that can provide training and certification in this area. Furthermore, due to the lack of regulation, any individual or organization that already holds a GCP certificate may provide training and certification to another individual or organization. 
Certification in project management is a knowledge-based and competency-based approach. In GCP, however, there is a knowledge-based certification only. There is a standard-setting organization in both project management and GCP fields, but in PM it grants an official accreditation to subsequent organizations. In GCP, training organizations are not officially accredited. A relatively common method of confirming the quality of their training is the so-called 'accreditation by TransCelerate' - a quasi-accreditation. In addition, in GCP, apart from organizations, the individuals who have undergone training and received a GCP cer-tificate are entitled to train and issue certificates. In PM, to be entitled to train others, trainers have to be officially accredited. Finally, in PM, there is a distinction between levels of competence, which is not present in GCP.

\subsection{In-depth interviews}

The conclusions from the answers given in the in-depth interviews confirmed indirectly that the list of stakeholders and relations between them were presented in the model of GCP certification adequately to respondents' view. However, the model itself is too general to distinguish the essential elements in the GCP certification process and their possible influence on the clinical trial quality and finally draw conclusions on how the certification process can be improved. The majority of obtained answers reflected the awareness of the environment concerning the current certification process and its acceptance. Only one respondent noticed that the process needs a change, but, nevertheless, only one admitted that the system is good enough and does not need any changes. The summary of the answers is presented as follows.

According to most respondents, the current GCP certification system is sufficient to check the knowledge of the GCP guidelines in a credible way (a certificate can be obtained, training courses are available, an unofficial accreditation system has already been set up, works and is recognized). There are many quasi-training products on the market, and there is no system to compare and verify them.

At present, it is also not possible to determine the level of knowledge of GCP guidelines. Only an efficiency threshold of $60-90 \%$ is determined, but the test can be taken several times. The certificate is merely a formal confirmation (as one of the possible forms) of completing GCP training. There is no need to accredit GCP training providers or to hold/issue certificates as such. Formal (e.g., written) approval of the training is entirely sufficient and can also occur in the form of a meeting and can be documented only, e.g., in an attendance list. 
When asked about the need for changes in the GCP certification process, the participants of the in-depth interviews indicated the necessity of limiting the number of training companies through a universal certification system - one certifying entity of high standard. However, they noted that currently, the market regulates and operates independently, although there is no system to check the level of skill quality. Unification of the environmental approach is advisable. Hence, the TransCelerate certification is accepted by a growing number of companies and probably all regulatory authorities. Additionally, the training and certification process itself can also be developed and changed locally, e.g., within a given site or company, by introducing a standard operation procedure (SOP). The fact that ICH does not require any certification is a specific advantage - ICH has decided not to impose its process, which can be placed on the market simultaneously.

Although there is no direct provision in the regulations for the required ICH-GCP certification, the word 'training' itself is clear enough for all regulators, inspectors, or companies conducting clinical trials. The ICH-GCP is a gold standard rooted in local and EU legislation, which is essential for conducting studies. The lack of official guidelines for the standardization of training or certification itself, including ICH-GCP, would only hinder this process.

\section{Discussion}

The purpose of this paper was to clarify the certification process of Good Clinical Practice (GCP) competencies based on a comparison with the project management certification process. The certification process presented in the model of GCP certification was prepared adequately for environmental awareness. However, it is too general to distinguish the important elements in the GCP certification process and their possible influence on the quality of the clinical trial conduct and results.

The GCP guidance standard is developed by a credible, international organization with a strong position. Thus, it seems possible for ICH to grant an existing organization (TransCelerate, BioPharma Inc.) or another accreditation body power to set certification standards. Considering the examples of project management solutions, the new role for ICH may be to strive for standardization of both the requirements for knowledge of GCP guidelines and the process of confirming knowledge in this area. It also seems justified to supplement the GCP knowledge assessment model with additional rules: 
1. Introduction of accreditation procedures for entities that provide GCP training and certification.

2. The application of a multilevel scale of certificates confirms the knowledge of the guidelines at various levels (adequate to the needs and workplace), e.g., level A, expert - confirmed by an exam in the form of a practical problem to be solved (case study); level B, advanced - confirmed by an exam in the form of open and closed questions; level C, intermediate - confirmed by an exam in the form of a test; level D, basic - confirmed by an exam in the form of a test. Consideration may be given to resigning from the $\mathrm{D}$ level examination in favor of the training completion test (as it is currently done).

3. The introduction of clear regulations for internal training and certification of knowledge of GCP guidelines, e.g., distinguishing between accredited and internal certificates, e.g., by giving them appropriate ranks.

The clinical trial environment accepts the current certification process, merely sees the flaws of the process, and does not seek its improvements. It should also be stressed that the clinical trial industry has adapted itself to the current standards of confirming knowledge of GCP guidelines. Therefore, any changes should be evolutionary, which will clarify and harmonize the candidates' requirements for GCP certificates and trainers. However, the source of these modifications should be the initiative of the clinical research community and not a top-down regulation. Clinical trial stakeholders are not aware of the close connotation between clinical trials and project management. Therefore, an increase in the awareness of these similarities will help accelerate the proposed modification. Finally, the conclusions and the GCP certification model could also be applied by the professionals and researchers in their business and scientific practice.

\section{Conclusions}

The paper fills a research gap in the Good Clinical Practice knowledge certification process in a substantial manner. In the healthcare sector, as in other areas of the economy, projects play an important role (Prawelska-Skrzypek $\&$ Jałocha, 2014). A clinical trial meets all requirements of the project definition (Doganov \& Yanev, 2006). There are numerous examples of adaptations of guidelines, standards, and practices in project management in clinical trial management (Goodarzynejad \& Babamahmoodi, 2015; Parvathaneni et al., 2018; Shirley, 2020). The good practices used by the standard-setting organizations 
and accreditation bodies as well as examiners and certifiers in the field of project management are clear and rational. Since the certification models are convergent in many aspects, it is possible to transfer these principles to clinical trial management successfully. However, clinical trial stakeholders do not seem to use the potential of these connotations in the area of the certification process.

The benchmarking exercise has shown that it is essential to distinguish between certification and a certificate. This distinction facilitates a correct identification of competencies. Certification is a confirmation of professionalism and high standards, and a certificate is a document confirming, e.g., training. The root of the conflation of certificates with certification in the clinical trial field is assumed to be an incorrect comprehension of these terms, which leads to the unregulated situation explained in the paper. Nevertheless, the interviewed respondents incorrectly identify the certification process with the obtained certificate.

There are some limitations in this study that should be addressed in future research. First, certification in project management covers a wide range of knowledge, broader than GCP. The proposed rules may be too complex and exceed the needs and expectations of the clinical trial environment. In addition, it may be considered a limitation to refer to general project management concepts and certify their knowledge without going into deeper analysis on narrower issues (e.g., quality management). Second, the models are focused on stakeholder relations, which omits the rules of certification granting procedures (i.e., expiration date, renewal procedure, required work experience), to enable broader contextualization of the issues discussed in the paper. Third, certification ensures possession of the necessary skills, but does not guarantee expertise or significantly increase the likelihood of project success (Catanio et al., 2013, p. 15). Thus, the analysis might be fragmented as it regards the sole certification process, not taking into account whether the project is accomplished successfully.

Finally, the research refers to Poland only, hence it will be valuable to identify whether foreign authorities have the same attitude to the GCP competency certification model. It is recommended to increase the number of respondents' interviews (five interviews conducted) to obtain results of higher validity and reliability. The authors predict that since the majority of sponsors of clinical trials operate globally, the attitude ought to be the same. However, it requires further investigation.

Continuing research in this direction may change the developed recommendations. The authors hope that the obtained results will trigger further research at 
the crossroads of project management, clinical trials, and GCP in the future and increase the awareness of their similarities. The prepared models might be an inspiration for future researchers to compare the fields mentioned in interdisciplinary studies.

The indirect aim of this paper was to draw attention to specific issues of GCP certification, the improvement of which, despite the lack of environmental requirements, will help transfer training effects into everyday practice. This may also contribute to the quality of clinical trials and provide public assurance that the rights, safety, and well-being of trial subjects are protected and the clinical trial data are credible, which was, after all, the main aim of creating GCP principles by ICH-GCP.

\section{Appendix}

Table 2. Detailed information about interviewed experts

\begin{tabular}{|c|l|c|l|}
\hline No. & \multicolumn{1}{|c|}{ Position } & Experience (years) & \multicolumn{1}{|c|}{ Expertise } \\
\hline A & Director & $10+$ & Pharma, Clinical Trials \\
\hline B & Line Manager & $5+$ & Academia, Clinical Trials \\
\hline C & Director & $10+$ & Academia, Clinical Trials \\
\hline D & Line Manager & $10+$ & Pharma, Clinical Trials \\
\hline E & Line Manager & $10+$ & Clinical Trials \\
\hline
\end{tabular}

Table 3. Interview questions

\begin{tabular}{|c|l|}
\hline No. & \multicolumn{1}{|c|}{ Question } \\
\hline 1 & Where does the need for GCP certification result from? \\
\hline 2 & Which entities are entitled to conduct GCP training? \\
\hline 3 & Are there any entities that grant GCP training providers accreditation? \\
\hline 4 & What are the possible sources of knowledge on GCP? \\
\hline 5 & $\begin{array}{l}\text { Is the current GCP certification system sufficient to check the knowledge of the GCP guidelines } \\
\text { reliably? }\end{array}$ \\
\hline 6 & How is the level of GCP knowledge verified? \\
\hline 7 & $\begin{array}{l}\text { Should changes to the process of certifying/confirming knowledge of the GCP guidelines } \\
\text { be introduced? }\end{array}$ \\
\hline
\end{tabular}


Table 4. Examples of interview answers

\begin{tabular}{|c|c|c|}
\hline No. & Question no. & Answers \\
\hline 1 & 3 & Expert B: "Yes, however, I am not aware of any accreditation providers". \\
\hline 2 & 3 & $\begin{array}{l}\text { Expert D: "There is no list of bodies that can conduct GCP training or be } \\
\text { authorized to provide the certificate". }\end{array}$ \\
\hline 3 & 4 & $\begin{array}{l}\text { Expert D: "No such bodies exist. According to a given standard, the only body } \\
\text { in the European market that validates ICH-GCP training is TransCelerate } \\
\text { BioPharma Inc.". }\end{array}$ \\
\hline 4 & 5 & Expert B: "No, it does not guarantee it". \\
\hline 5 & 5 & Expert C: "There is no such system". \\
\hline 6 & 6 & $\begin{array}{l}\text { Expert A: "I think that, regarding the need for knowing the GCP guidelines, it is } \\
\text { not possible to determine/assess the level of knowledge. The GCP guidelines } \\
\text { clearly state that knowledge is required (presumption of full knowledge) just like } \\
\text { the law". }\end{array}$ \\
\hline 7 & 7 & Expert A: "I believe that the existing system is sufficient". \\
\hline 8 & 7 & Expert C: "Quality control is a desired feature". \\
\hline 9 & 7 & $\begin{array}{l}\text { Expert E: "There are no scales or specific levels of verification because there } \\
\text { are no such requirements or expectations. However, as in any other training, } \\
\text { knowledge verification is (generally) based on a final test". }\end{array}$ \\
\hline 10 & 7 & $\begin{array}{l}\text { Expert E: "Of course, unification of the clinical trial stakeholders' approach is } \\
\text { advisable. Hence, among other things, the TransCelerate certification was } \\
\text { established, an increasing number of companies accept it and probably } \\
\text { all regulatory authorities have already done it". }\end{array}$ \\
\hline
\end{tabular}

\section{Acknowledgements}

We thank the anonymous reviewers and editorial team for their valuable comments and suggestions, and for help provided during the editorial process. They professional guidance helped us give the final shape to this article.

\section{References}

American Association of Legal Nurse Consultants. (n.d.). Certification vs. certificate. Retrieved from http://www.aalnc.org/page/certification-vs.-certificate

American Society for Engineering Management [ASEM]. (n.d.). Overview of the ASEM certification options. Retrieved from https://www.asem.org/Education/Certification

APMG. (n.d.). Certifications \& solutions. Retrieved from https://apmg-international.com/ certifications-solutions

Axelos. (n.d.). What is ITIL®? Retrieved from https://www.axelos.com/best-practicesolutions/itil/what-is-itil 
Blomquist, T., Farashah, A. D., \& Thomas, J. (2018). Feeling good, being good and looking good: Motivations for, and benefits from, project management certification. International Journal of Project Management, 36(3), 498-511. https://doi.org/ 10.1016/j.ijproman.2017.11.006

Bracewell, N., \& Winchester, D. E. (2021). Accreditation in health care: Does it make any difference to patient outcomes? BMJ Quality \& Safety. https://doi.org/10.1136/ bmjqs-2020-012533

Calza, E., \& Goedhuys, M. (2021, February). Just a piece of paper? Domestic standards certification and small firm growth in Viet Nam. The Journal of Development Studies. https://doi.org/10.1080/00220388.2021.1873289

Cambridge Dictionary. (n.d.). Meaning of certification in English. Retrieved from https://dictionary.cambridge.org/dictionary/english/certification

Catanio, J., Armstrong, G., \& Tucker, J. (2013, February). Project management certification and experience: The impact on the triple constraint. Journal of Advances in Information Technology, 4(1), 8-19. https://doi.org/10.4304/jait.4.1.8-19

Cheng, L. T. W., Sharma, P., Shen, J., \& Ng, A. C. C. (2021, April). Exploring the dark side of third-party certification effect in B2B relationships: A professional financial services perspective. Journal of Business Research, 127, 123-136. https://doi.org/ 10.1016/j.jbusres.2021.01.031

Cilenti, D. (2021). Innovation theory and local health department accreditation. American Journal of Public Health, 111(2), 183-184. https://doi.org/10.2105/AJPH.2020. 306076

Construction Management Association of America [CMAA]. (n.d.). Certification. Retrieved from https://www.cmaanet.org/certification

Doganov, B. K., \& Yanev, S. (2006). Implementation of project management principles in clinical trial process. Paper presented at PMI® Global Congress 2006-EMEA, Madrid, Spain. Newtown Square, PA: Project Management Institute. Retrieved from https://www.pmi.org/learning/library/project-management-principles-clinicaltrial-pharmaceutical-8206

Directive 2001/20/EC. On the approximation of the laws, regulations and administrative provisions of the Member States relating to the implementation of good clinical practice in the conduct of clinical trials on medicinal products for human use. European Parliament, Council of the European Union. Retrieved from https://ec. europa.eu/health//sites/health/files/files/eudralex/vol-1/dir_2001_20/dir_2001_20_ en.pdf

Directive 2005/28/EC. Laying down principles and detailed guidelines for good clinical practice as regards investigational medicinal products for human use, as well as the requirements for authorisation of the manufacturing or importation of such products. European Commission. Retrieved from https://eur-lex.europa.eu/eli/dir/ 2005/28/oj 
Englev, E., \& Petersen, K. P. (2003). ICH-GCP Guideline: kvalitetssikring af kliniske laegemiddelforsøg. Status og perspektiver [ICH-GCP Guideline: quality assurance of clinical trials. Status and perspectives]. Ugeskrift for laeger, 165(16), 16591662.

European Medicines Agency. (2002, July). ICH topic E 6 (R1) guideline for good clinical practice. Retrieved from https://www.ema.europa.eu/en/documents/scientificguideline/ich-e6-r1-guideline-good-clinical-practice_en.pdf

Fougerou-Leurent, C., Chesnais, J., Nekmouche, S., Veislinger, A., Le Saux, M., Joumard, C., Lorre, V., Bellot, C., Alleton, N., Labourdette, E., Marie, C., Fin, L., Bellissant, E., \& Laviolle, B. (2020). Enquête sur la certification aux bonnes pratiques cliniques en recherche académique [A survey on French hospital physicians' certification to the Good Clinical Practices]. Therapie, 75(6), 537-542.https://doi. org/10.1016/j.therap.2020.04.002

Gasik, S. (2010). A model of project knowledge management. Project Management Journal, 42(3), 23-44. https://doi.org/10.1002/pmj.20239

Goodarzynejad, H., \& Babamahmoodi, A. (2015, August). Project management of randomized clinical trials: A narrative review. Iranian Red Crescent Medical Journal, 17(8), e11602. https://doi.org/10.5812/ircmj.11602

Haeusler, J.-M. C. (2009). Certification in Good Clinical Practice and clinical trial quality: A retrospective analysis of protocol adherence in four multicenter trials in the USA. Clinical Research and Regulatory Affairs, 26(1-2), 20-23. https://doi.org/ 10.1080/10601330902911893

Hallgren, M., Nilsson, A., Blomquist, T., \& Soderholm, A. (2012). Relevance lost! A critical review of project management standardisation. International Journal of Managing Projects in Business, 5(3), 457-485. https://doi.org/10.1108/175383712 11235326

Hulihan, E. W. (2017). Good Clinical Practice: A question \& answer reference guide. Needham, MA: Barnett International.

Institute for Credentialing Excellence. (2010). Defining features of quality certification and assessment-based certificate programs. Washington, D.C.: Author.

International Project Management Association. (n.d.). Become recognised as a professional - certification. Retrieved from https://www.ipma.world/individuals/ certification/

Jones, A., \& Shideh, R. (2021). The significance of knowledge management in the knowledge economy of the 21 st century. International Journal of Innovation, Creativity and Change, 15(2), 366-377.

Juchniewicz, M. (2018). Projektyzacja - koncepcja, zakres, konsekwencje [Projectification - concept, scope, consequences]. Studia i Prace. Kolegium Zarzadzania i Finansów, 159, 43-58.

Kerzner, H. (2013). Project management: A systems approach to planning, scheduling, and controlling. New Jersey: John Wiley \& Sons. 
Kohl, H. (2020). Certification and accreditation: Types and rules. In Standards for management systems. Management for professionals (pp. 669-688). Cham: Springer. https://doi.org/10.1007/978-3-030-35832-7_8

Legard, R., Keegan, J., \& Ward, K. (2014). In-depth interviews. In J. Ritchie, \& J. Lewis (Eds.), Qualitative research practice: A guide for social science students and researchers (2nd ed., pp. 138-139). London: Thousand Oaks, New Delhi: Sage Publications.

Nazeer, J., \& Marnewick, C. (2018). Investing in project management certification: Do organisations get their money's worth? Information Technology and Management, 19(1), 4, 51-74. https://doi.org/10.1007/s10799-017-0275-y

Nowicki, P., \& Kafel, P. (2021). Remote certification processes during global pandemic times. SHS Web of Conf, 92, Article 01037, 1-9. https://doi.org/10.1051/shsconf/ 20219201037

Oleksyn, T. (2010). Zarzadzanie kompetencjami. Teoria i praktyka [Competence management. Theory and practice]. Warszawa: Wolters Kluwer.

Parvathaneni, M., Pattarkine, M., \& Chappidi, D. (2018). Implementation of project management in clinical research. Inventi Rapid: Clinical Research, 2018(1), 1-6.

Patalas-Maliszewska, J. (2019). Modele referencyjne $w$ zarządzaniu wiedza $w$ przedsiębiorstwie produkcyjnym [Reference models for knowledge management in a production company]. Warszawa: Wydawnictwo Naukowe PWN.

Pawlak, M. (2006). Zarzadzanie projektami [Project management]. Warszawa: Wydawnictwo Naukowe PWN.

Pietras, P., \& Szmit, M. (2003). Zarzadzanie projektami. Wybrane metody i techniki [Project management. Selected methods and techniques]. Lódź: Oficyna Księgarsko-Wydawnicza „Horyzont”.

Prawelska-Skrzypek, G., \& Jałocha, B. (2014). Projektyzacja sektora publicznego w Polsce - implikacje dla samorządu terytorialnego [Public sector projectification in Poland - implications for local government]. Zarzadzanie Publiczne, 3(27), 273-284. https://doi.org/10.4467/20843968ZP.14.023.2767

Project Management Institute. (n.d.). Certifications. Retrieved from https://www. pmi.org/certifications

Public Responsibility in Medicine and Research. (n.d.). Certificate versus certification. Retrieved from https://www.primr.org/certificates/

PwC. (2015). Badania kliniczne w Polsce [Clinical trials in Poland]. Retrieved from https://www.pwc.pl/pl/pdf/clinical-trials-in-poland-pwc-report.pdf

Quality Magazine. (2016, November). Certificates vs. certifications. Retrieved from https://www.qualitymag.com/articles/93658-certificates-vs-certifications

Regulation 536/2014. On clinical trials on medicinal products for human use, and repealing Directive 2001/20/EC. European Parliament, Council of the European Union. Retrieved from https://ec.europa.eu/health/sites/health/files/files/eudralex/vol1/reg_2014_536/reg_2014_536_en.pdf 
Remer, D. S., \& Ross, E. M. (2014). Review of project and engineering management certification offered by professional organizations. Engineering Management Journal, 26(4), 3-12. https://doi.org/10.1080/10429247.2014.11432023

Rozporzadzenie Ministra Zdrowia z dnia 2 maja 2012 r. w sprawie Dobrej Praktyki Klinicznej [Regulation of the Minister of Health of 2 May 2012 on Good Clinical Practice]. Retrieved from http://isap.sejm.gov.pl/isap.nsf/DocDetails.xsp?id=wdu 20120000489

Scrum Alliance. (n.d.). Certification types \& tracks. Retrieved from https://www. scrumalliance.org/get-certified

Schmidt, R., Bell, R., \& Warren, V. (2021). Keeping the wheels of the automotive industry turning: The use of tacit knowledge by product development workers in a multinational automotive manufacturer. Journal of Intellectual Capital, 22. https://doi.org/10.1108/JIC-07-2020-0257

Shirley, D. (2020). Project management for healthcare. Boca Raton: Taylor \& Francis.

Starkweather, J. A., \& Stevenson, D. H. (2010). PMP® certification as a core competency: Necessary but not sufficient. Project Management Journal, 42(1), 31-41. https://doi.org/10.1002/pmj.20174

Strojny, J., \& Szmigiel, K. (2015). Analiza porównawcza podejść w zakresie zarządzania projektami [Comparative analysis of project management approaches]. Modern Management Review, XX(22/3), 249-265. https://doi.org/10.7862/rz.2015.mmr.48

Swain, N. (2000). Project management certification. Info World, 22(44), 79-88.

Swapan, B., \& Bhaswati, S. (2020). Importance of international accreditation for institutions and the role of private certification bodies. Asian Journal of Management, 11(3), 39-43. https://doi.org/10.5958/2321-5763.2020.00043.8

The International Council for Harmonisation of Technical Requirements for Pharmaceuticals for Human Use. (1996). Guideline for Good Clinical Practice E6(R1). ICH Harmonised Tripartite Guideline. Retrieved from https://www.ema.europa.eu/en/ ich-e6-r2-good-clinical-practice

The United States Food and Drug Administration. (2018). E6(R2) Good Clinical Practice: Integrated addendum to ICH E6(RI) guidance for industry. Retrieved from https://www.fda.gov/media/93884/download

TransCelerate Biopharma Inc. (n.d.). GCP mutual recognition. Retrieved from https:// transceleratebiopharmainc.com/gcp-training-attestation/

Urząd Rejestracji Produktów Leczniczych, Wyrobów Medycznych i Produktów Biobójczych [Office for Registration of Medicinal Products, Medical Devices and Biocidal Products]. (2020). Biuletyn produktów leczniczych ludzkich 2019 [Human medicinal products bulletin 2019]. Retrieved from http://urpl.gov.pl/sites/ default/files/zalaczniki/Biuletyn\%20URPL\%202019_PL.PDF

Ustawa z dnia 6 września 2001 r. Prawo farmaceutyczne [Act of 6 September 2001. Pharmaceutical law]. Retrieved from https://isap.sejm.gov.pl/isap.nsf/DocDetails. xsp?id=WDU20011261381 
Wang, X., Zhang, X., Xiong, H., \& de Pablos, P. O. (2020). KM 3.0: Knowledge management computing under digital economy. In F. Matos, V. Vairinhos, I. Salavisa, L. Edvinsson, \& M. Massaro (Eds.), Knowledge, people, and digital transformation. contributions to management science (pp. 207-217). Cham: Springer. https://doi.org/10.1007/978-3-030-40390-4_13

Wawak, S. (2009, June). Certyfikacja [Certification]. Retrieved from https://wawak.pl/ $\mathrm{pl} /$ content/certyfikacja

Wells, H. (2012). How effective are project management methodologies? An explorative evaluation of their benefits in practice. Project Management Journal, 43(6), 43-58. https://doi.org/10.1002/pmj.21302

World Bank. (2007). Building knowledge economies. Washington, D.C.: Author.

World Medical Association. (2020, July). WMA Declaration of Helsinki-ethical principles for medical research involving human subjects. Retrieved from https:// www.wma.net/policies-post/wma-declaration-of-helsinki-ethical-principles-formedical-research-involving-human-subjects/

Yıldız, M. S., Öztürk, Z., Topal, M., \& Khan, M. M. (2019). Effect of accreditation and certification on the quality management system: Analysis based on Turkish hospitals. International Journal of Health Planning \& Management, 34(4), e1675-e1687. https://doi.org/10.1002/hpm.2880 